\title{
Peran Media Massa dalam Menyampaikan Informasi Pemilu 2019 di Kabupaten Tanjung Jabung Timur
}

\author{
Edi Dwi Abimayu, Muhaimin, Sururuddin, M. Junaidi \\ UIN Sulthan Thaha Saifudin Jambi \\ Email: edidwiabimayu98@gmail.com
}

\begin{abstract}
Abstrak: Terbatasnya akses penyebaran media massa di Tanjab Timur dan minimnya kesadaran masyarakat dalam mengakses media massa menjadi latar belakang penelitian ini. Tujuan penelitian membahas peran media massa dalam menyampaikan informasi pemilu 2019, bagaimana cara KPUD memanfaatkan media massa dalam menyampaikan informasi pemilu 2019, media apa yang digunakan dan informasi apa yang disampaikan serta kendala dan hambatan apa yang terjadi. Metode yang digunakan yaitu menggunakan metode kualitatif deskriftif yaitu penelitian ini diartikan sebagai suatu usaha pencarian kebenaran terhadap fenomena, fakta, atau segala gejala dengan cara ilmiah untuk memecahkan masalah atau mengembangkan ilmu pengetahuan. Pendekatan penelitian yang digunakan yaitu Studi kasus termasuk dalam penelitian analisis deskriptif. Metode analisis data yang digunakan adalah analisis domain dan analisis teksonomi sedangkan metode keabsahan data yang digunakan diantaranya perpanjangan keikutsertaan, ketekunan pengamatan dan diskusi dengan teman sejawat. Kesimpulan penelitian ini yaitu penyebaran informasi pemilu yang dilakukan oleh KPU menggunakan berbagai macam media massa dan membentuk relawan domokrasi tujuannya untuk meningkatkan kualitas pemilu, partisipasi pemilih, dan kepercayaan public terhadap proses demokrasi yang dilakukan di wilayah Kabupaten Tanjung Jabung Timur.
\end{abstract}

Kata-kata kunci: media massa, informasi pemilu 2019, Tanjabtim.

\section{A. Pendahuluan}

Informasi merupakan kebutuhan utama setiap orang. Informasi semakin dibutuhkan oleh banyak orang untuk mengembangkan kepribadian pada lingkungan sosialnya. Atas dasar itu informasi banyak hal telah tercipta, termasuk 
salah satunya teknologi yang semakin berkembang. Bagian terpenting dalam berkomunikasi adalah informasi, karena tanpa informasi yang baik seseorang tidak akan bisa berkomunikasi dengan baik pula dan tanpa informasi juga seseorang tidak akan mampu untuk berkembang ke arah yang lebih baik.

Keberadaan media massa menduduki posisi yang sangat strategis terutama dalam memberikan akses bagi mereka yang membutuhkan informasi. Sesuai sifat kodrati manusia yakni rasa ingin tahu terhadap segala sesuatu, kehadiran media massa dianggap dapat membantu manusia dalam memberikan akses bagi orang-orang untuk memperoleh informasi yang mereka butuhkan. Seiring dengan perkembangan kebutuhan manusia yang semakin kompleks, peran media pun semakin berkembang. Media tidak hanya berperan memberikan akses informasi semata, namun secara tidak sadar media dapat mempengaruhi opini publik dan menggiring persepsi masyarakat sesuai tujuannya.

Di era sekarang peranan media sangat penting sekali antara lain, melaporkan fakta dan memberikan informasi, mendidik publik, memberi komentar, dan menyampaikan dan membentuk opini publik. Media dapat dengan leluasa mengkritik, mengatur dan mengontrol pemerintah dan semua pelaku politik, kader partai yang terpilih maupun tidak terpilih, dan wakil LSM.

Menurut McQuail mengemukakan beberapa peran media antara lain, yaitu: Media dipandang sebagai jendela yang memungkinkan khalayak melihat apa yang sedang terjadi. Media merupakan sarana belajar untuk mengetahui berbagai peristiwa. Media menjadi cermin berbagai peristiwa yang ada di masyarakat dan dunia, yang merefleksikan apa adanya. Media sebagai filter, menyeleksi berbagai hal untuk diberi perhatian atau tidak. Media senantiasa memilih issue, informasi atau bentuk content yang lain berdasar standar para pengelolanya. Media dianggap sebagai penunjuk arah yang menerjemahkan dan menunjukkan arah atas berbagai ketidakpastian, atau alternative yang beragam. Media massa sebagai forum untuk mempresentasikan berbagai informasi dan ide-ide kepada masyarakat, sehingga memungkin terjadinya tanggapan dan umpan balik. Selain 
itu media massa tidak hanya sekadar tempat untuk memberikan informasi, tetapi juga partner komunikasi yang memungkinkan terjadinya komunikasi interaktif. ${ }^{1}$

Media tidak hanya sebagai pelepas ketegangan atau hiburan, tetapi isi dan informasi yang disajikan dapat mempengaruhi realitas subjektif masyarakat. Gambaran tentang realitas yang dibentuk oleh isi media massa inilah yang nantinya mendasari respon dan sikap khalayak terhadap berbagai informasi yang diberitakannya. Informasi yang salah dari media massa akan memunculkan gambaran yang salah pula terhadap informasinya. Oleh karenanya media massa dituntut menyampaikan informasi secara akurat dan berkualitas. Kualitas informasi inilah yang merupakan tuntutan etis dan moral penyajian media massa.

Dewasa ini media mempunyai posisi yang paling strategis dan mempunyai senjata yang ampuh untuk dapat mempengaruhi opini publik dan menggiring persepsi masyarakat sesuai tujuannya. Diselenggarakannya pemilihan umum melahirkan elit-elit politik, peran media adalah mengawasi dan memberikan informasi kepada publik atas aktivitas-aktivitas dan keputusan-keputusan politik yang dilakukan oleh para elit politik. Aktivitas dan kebijakan politik akan menjadi sentra perhatian dan secara tidak langsung akan membentuk opini dalam masyarakat. Masyarakat akan merespon keputusan atau kebijakan yang disampaikan para elit politik dan menjadi pedoman bagi para elit untuk mengambil langkah-langkah tentang keputusan atau kebijakan yang mereka keluarkan, hingga masyarakat (publik) akan menerima keputusan tersebut.

Salah satu ciri negara demokrasi adalah diselenggarakannya pemilu yang terjawal dan berkala. Tanpa terselengaranya pemilu maka hilanglah sifat demokrasi suatu negara. Demikian agar sifat negara demokratis tersebut dapat terjamin oleh adanya pemilu, maka penyelengara pemilu harus dilaksanakan secara berkualitas. ${ }^{2}$

\footnotetext{
${ }^{1}$ McQuail, Dennis, McQuail's Mass Communication Theory, (New Delhi: SAGE Publication, 2000), 66.

${ }^{2}$ Galuh Kartiko, Sistem Pemilu dalam Perspektif Demokrasi di Indonesia, (Jurnal Konstitusi, Volume II, Nomor 1 Juni 2009).
} 
Komisi Pemilihan Umum (KPU) adalah lembaga negara yang menyelenggarakan pemilihan umum di Indonesia, yakni meliputi Pemilihan Umum Anggota DPR/DPD/DPRD, Pemilihan Umum Presiden dan Wakil Presiden, serta Pemilihan Umum Kepala Daerah dan Wakil Kepala Daerah. Komisi Pemilihan Umum tidak dapat disejajarkan kedudukannya dengan lembaga -lembaga negara yang lain yang kewenangannya ditentukan dan diberikan oleh UUD $1945 .^{3}$

Di dalam Undang Undang Nomor 7 Tahun 2017 tentang pemilihan umum pada pasal 1 angka 1 dinyatakan bahwa pemilu adalah sarana kedaulatan rakyat untuk memilih anggota Dewan Perwakilan Rakyat, Dewan Perwakilan Daerah, Presiden dan wakil Presiden, dan untuk memilih anggota Dewan Perwakilan Rakyat Daerah, yang dilaksanakan secara langsung, umum, bebas, rahasia, jujur, dan adil dalam negara kesatuan republic Indonesia bedasarkan Pancasila dan undang undang dasar negara republic Indonesia tahun 1945. Pada pasal 2 dinyatakan bahwa pemilu dilaksanakan bedasarkan asas langsung, umum, bebas, rahasia, jujur, dan adil.

Jika dibaca dari pengertian dari kedua pasal tersebut, pelaksanaan pemilu sebagai bentuk pelaksanaan kedaulatan rakyat. Karena rakyat yang memiliki daulat itu maka aspek penyelenggaraan pemilu itu harus dikembalikan kepada rakyat lagi, seperti bagaimana mengawasi bisnis proses pelaksanaan pemilu. Dengan begitu harapan penyelengaraan pemilu, yakni melahirkan pemerintahan yang demokratis sesuai dengan Pancasila dan UUD 1945, dapat dilaksanakan.

Tantangan sosialisasi dan Pendidikan pemilih pada pemilu 2019 akan lebih berat karena semakin kompleksnya penyelenggara pemilu. Pemilih akan berhadapan dengan lima jenis surat suara di TPS. Butuh kecermatan pemilih untuk memastikan tata cara pemberian suara yang benar ditempat pemungutan suara (TPS). Sosialisasi dan Pendidikan pemilih akan lebih masif dan intensif juga dibutuhkan untuk menurunkan angka suara tidak sah dalam pemilu.

3 Seputar Pengertian, "Pengertian KPU Beserta Fungsinya", diakses melalui alamat http://seputar pengertian.blogspot.com/2015/12/pengertian-kpu-beserta-fungsinya.html, tanggal 27 Juni 2019. 
Peran media massa sebagai sarana informasi pemilihan umum di Kabupaten Tanjung Jabung Timur sangat penting sekali yaitu untuk meningkatkan kualitas proses pemilu, meningkatkan partisipasi pemilih, meningkatkan kepercayaan public terhadap proses demokrasi, dan membagkitkan kesukarelaan masyarakat sipil dalam agenda pemilu dan demokrasi.

Kajian terhadap peran media massa dalam menyampaikan informasi pemilu 2019 di kabupaten Tanjung jabung timur, menggunakan metode penelitian kualitatif atau data yang ada di lapangan. Bergantung pada pengamatan manusia, dengan alasan memiliki latar alami (the natural setting), bersifat deskriptif, lebih memperhatikan proses dari pada hasil, dan menganalisa data secara induktif, di mana makna menjadi hal yang esensial.

Setting penelitian ini di Kantor KPUD Tanjung Jabung Timur. dengan alasan masih dihadapkan pada: Pertama, permasalahan kurangnya pememfaatan media massa sebagai sarana penyampaian informasi pemilu 2019. Kedua, kajian tempat penelitian ini belum pernah diteliti untuk dilakukan penelitian. Ketiga, kemudahan akses data dari lapangan. Subjek penelitian berpusat pada Ketua KPUD, Komisioner KPUD dan jajaran staf. Jenis data yang digunakan meliputi data primer dan data sekunder. Dilihat dari sumber data, bahan tambahan yang berasal dari sumber tertulis dapat dibagi atas sumber buku, majalah ilmiah, arsip dokumen pribadi dan dokumen resmi. Prosedur pengumpulan data dalam studi ini menggunakan tiga teknik yang dilakukan secara berulang-ulang agar keabsahan datanya dapat di pertanggung jawabkan, yaitu: Metode Observasi, Metode Wawancara, dan Metode Dokumentasi. ${ }^{4}$

\section{B. Sejarah KPU di Indonesia}

Walaupun Pemilu 1955 dikenal sebagai Pemilu pertama di Indonesia namun sejarah pembentukan lembaga penyelenggaraan pemilu sudah dimulai

\footnotetext{
240.

${ }^{4}$ Sugiono, Metode Penelitian Kuantitatif, Kualitatif, dan R\&D (Bandung: Alfabeta, 2010), 
pada tahun 1946 ketika Presiden Soekarno membentuk Badan Pembentuk Susunan Komite Nasional Pusat, menyusun disahkannya Undang-Undang Nomor 12 Tahun 1946 tentang Pembaharuan Susunan Komite Nasional Indonesia Pusat (UU No. 12 Tahun 1946). Setelah revolusi kemerdekaan pada tanggal 7 November 1953 Presiden Soekarno menandatangani Keputusan Presiden Nomor 188 Tahun 1955 tentang pengangkatan Panitia Pemilihan Indonesia (PPI) Panitia inilah yang bertugas menyiapkan, memimpin dan menyelenggarakan pemilu 1955 untuk memilih anggota Konstituante dan Anggota Dewan Perwakilan Rakyat.

Undang-undang Nomor 7 Tahun 1953 tentang Pemilihan Anggota Konstituante dan Anggota Dewan Perwakilan Rakyat disahkan pada 4 April 1953 dan menyebutkan PPI berkedudukan di ibukota Negara. Panitia Pemilihan Daerah (PPD) berkedudukan di setiap daerah pemilihan. Panitia Pemilihan Kabupaten berkedudukan di setiap kecamatan. Panitia pendaftaran pemilihan berkedudukan di setiap desa dan panitia pemilihan luar negeri. PPI ditunjuk oleh Presiden, Panitia Pemilihan ditunjuk oleh Menteri Kehakiman dan Panitia Pemilihan Kabupaten ditunjuk oleh Menteri Dalam Negeri. Pemilu yang pertama kali tersebut berhasil diselenggarakan dengan aman, lancar, jujur dan adil serta sangat demokratis.

Sangat disayangkan, kisah sukses Pemilu 1955 akhirnya tidak bisa dilanjutkan, dan hanya menjadi catatan emas sejarah. Pemilu pertama itu tidak berlanjut dengan Pemilu kedua lima tahun berikutnya, meskipun ditahun 1958 Pejabat Presiden Sukarno sudah melantik Panitia Pemilihan Indonesia II, yang terjadi kemudian adalah berubahnya format politik dengan keluarnya Dekrit Presiden 5 Juli 1959. Presiden Soekarno secara sepihak membentuk DPR-Gotong Royong (DPR-GR) dan MPR Sementara (MPRS) yang semua anggotanya diangkat oleh Presiden. Pada Dektrit itu pula Presiden Soekarno membubarkan Konstituante dan mengutarakan pernyataan untuk kembali ke UUD 1945 yang diperkuat angan-angan Presiden Soekarno menguburkan kepartaian di Indonesia. Dekrit itu kemudian mengakhiri rezim demokrasi dan mengawali otoriterianisme 
kekuasaan di Indonesia. Otoriterianisme pemerintahan Presiden Soekarno makin jelas ketika pada 4 Juni 1960, ia membubarkan DPR hasil Pemilu 1955.

Pengangkatan keanggotaan MPR dan DPR, dalam arti tanpa pemilihan memang tidak bertentangan dengan UUD 1945. Karena UUD 1945 tidak memuat klausul tentang tata cara memilih anggota DPR dan MPR. Rezim yang kemudian dikenal dengan sebutan Demokrasi Terpimpin itu tidak pernah sekalipun menyelenggarakan Pemilu Kepresidenan. Malah tahun 1963 MPRS yang anggotanya diangkat Soekarno, diinstruksikan untuk menetapkan orang yang mengangkatnya menjadi Presiden seumur hidup. Ini adalah satu bentuk kekuasaan otoriter yang mengabaikan kemauan rakyat. Presiden Soekarno diberhentikan oleh MPRS melalui Sidang Istimewa bulan Maret 1967 (Ketetapan XXXIV/MPRS/ 1967) setelah meluasnya krisis politik, ekonomi dan sosial pasca kudeta G 30 S/PKI.

Tongkat kepemerintahan Republik Indonesia selanjutnya diserahkan kepada Soeharto menggantikan jabatan Presiden Soekarno. Dimasa kepemerintahan orde baru Presiden Soeharto membentuk Lembaga Pemilihan Umum (LPU) yang bertugas sebagai badan penyelenggara pemilihan umum di Indonesia. LPU terbentuk berdasarkan Keppres No 3 Tahun 1970 diketuai oleh Menteri Dalam Negeri yang keanggotaannya terdiri atas Dewan Pimpinan, Dewan Pertimbangan, Sekretariat Umum LPU dan Badan Perbekalan dan Perhubungan. Menyusul runtuhnya rezim orde baru yang diakibatkan gejolak politik dimasyarakat. Presiden Soeharto mengumumkan pemunduran dirinya sebagai Presiden Republik Indonesia dari kekuasaannya pada tanggal 21 Mei 1998 dan jabatan ke Presidenan selanjutnya digantikan oleh Wakil Presiden Bacharuddin Jusuf Habibie. Pada masa inilah sejarah Komisi Pemilihan Umum di Indonesia pertama kali dibentuk melalui Keppres No 16 Tahun 1999.

LPU yang dibentuk Presiden Soeharto pada 1970 itu ditransformasi menjadi Komisi Pemilihan Umum dengan memperkuat peran, fungsi dan struktur organisasinya menjelang pelaksanaan pemilu 1999. Saat itu KPU diisi oleh wakil 
wakil pemerintah dan wakil-wakil peserta pemilu 1999 serta tokoh-tokoh masyarakat yang berjumlahkan 53 anggota dan dilantik oleh Presiden BJ.Habibie. Pembentukan KPU dilakukan mengingat desakan publik yang menuntut pemerintahan yang demokratis. Pada saat itu untuk sebagian alasan diadakannya pemilu, adalah untuk memperoleh pengakuan atau kepercayaan dari publik, termasuk dunia internasional, karena kepemerintahan dan lembaga-lembaga lain yang merupakan produk Pemilu 1997 pemerintahan orde baru sudah dianggap tidak mendapat kepercayaan lagi oleh masyarakat.

Dengan pemilu dipercepat, yang terjadi bukan hanya bakal digantinya keanggotaan DPR dan MPR sebelum selesai masa kerjanya, tetapi Presiden Habibie sendiri memangkas masa jabatannya yang seharusnya berlangsung sampai tahun 2003, suatu kebijakan dari seorang presiden yang belum pernah terjadi sebelumnya. Pemilu ditahun 1999 itu sendiri menghasilkan kemenangan bagi pasangan calon K.H Abdurrahman Wahid (Gus Dur) dan Megawati Soekarno Putri sebagai Presiden dan wakil Presiden RI yang ke 3. Dimasa jabatan Presiden Addurrahman Wahid, beliau melakukan perombakan struktur KPU melalui Keppres No 70 Tahun 2001. Perombakan struktur KPU ini merupakan upaya perbaikan dari pembentukan KPU sebelumnya dijaman pemerintahan Presiden BJ.Habibie. Perombakan struktur tersebut dapat dilihat dari pemangkasan struktur penjabat KPU yang sebelumnya beranggotakan 53 orang.

Struktur KPU pada masa Presiden Abdurrahman Wahid ini terdiri dari unsur LSM serta akademisi yang beranggotakan berjumlah 11 orang. Hal ini dibuat supaya mekanisme kerja komisi pemilihan umum dapat berjalan lebih efektif dibandingkan dengan KPU sebelumnya yang beranggotakan 53 orang. Pelantikan struktur KPU tersebut dilakukan pada tanggal 11 april 2001 dan dilantik secara langsung oleh Presiden Abdurrahman Wahid. Pada periode pemilu kedua pasca orde baru ini Pemilu dilaksanakan lebih tertib dan konfrehensif mengingat perubahan-perubahan yang terus dilakukan untuk membenahi dan memperbaiki sistem pemilihan umum di Indonesia. 
Pemilu kedua ini menghasilkan pasangan calon Megawati Soekarno Putri dan Prof.Dr.H. Hamza Haz sebagai Presiden dan Wakil Presiden RI yang ke-4. Setahun pasca pergantian Kepemimpinan Negara, Presiden Megawati Soekarno Putri merancang Keppres mengenai pembentukan tim seleksi anggota KPU. Fungsi dari tim seleksi yang dibuat adalah membantu Presiden untuk menetapkan calon anggota KPU yang baru dan diajukan kepada Dewan Perwakilan Rakyat untuk dilakukan pemilihan secara demokratis. Dalam melaksanakan tugasnya tim seleksi anggota KPU bertanggung jawab kepada Presiden. Pembentukan tim seleksi anggota KPU ini dibuat berdasarkan Keppres No 67 Tahun 2002 untuk membentuk kepengurusan KPU dalam menghadapi Pemilihan umum di Tahun 2004 yang akan datang.

Pembentukan tim seleksi anggota KPU bertujuan untuk mengangkat kepengurusan KPU yang pertama pasca perbaikan struktur KPU yang dilakukan Presiden Abdurrahman Wahid. Pada Pemilu 2004 menghasilkan pasangan calon Susilo Bambang Yudhoyono dan H.M. Yussuf Kalla sebagai Presiden dan Wakil Presiden RI ke-5. Massa jabatan Presiden Susilo Bambang Yudhoyono mempunyai keistimewaan tersendiri dipasca era reformasi demokrasi. Beliau memenangkan 2 kali tahapan Pemilu Presiden mengalahkan saingan lainnya di Pemilu 2004 dan 2009. Presiden SBY merombak pasangan wakil Presiden ditahap ke dua masa jabatanya menjadi Prof.Dr. Boediono, M.Ec. sebagai Wakil Presiden Republik Indonesia. Pembentukan kepengurusan KPU yang kedua ini dilakukan berdasarkan Keppres No 12 Tahun 2007 mengenai pembentukan tim seleksi keanggotaan KPU.

Tim seleksi calon anggota KPU yang terakhir (ketiga), dibentuk berdasarkan Keppres Nomor 33 Tahun 2011 tentang Pembentukan Tim Seleksi Calon Anggota KPU tanggal 2 December 2011 yang ditanda tangani oleh Presiden Republik Indonesia Susilo Bambang Yudhoyono. Pembentukan tim seleksi ini dilakukan dalam rangka melaksanakan ketentuan Undang-Undang No. 15 tahun 2011 dan undang-undang sebelumnya pasca perbaikan tentang Penyelenggaraan Pemilhan 
Umum. KPU yang ketiga ini mempunyai jumlah sebanyak 7 orang anggota dan terdiri dari peneliti, birokrat, serta akademisi. ${ }^{1}$

\section{Penggunaan Media dalam Menyampaikan Informasi Pemilu 2019}

Dalam buku Hidajanto dan Andi dijelaskan bahwa teori stimulus respon adalah teori tertua dalam teori komunikasi linear. Teori stimulus repson pada dasarnya merupakan suatu prinsip belajar yang sederhana, dimana efek merupakan reaksi terhadap stimulus tertentu. Maka dari itu, individu dapat menjelaskan suatu kaitan antara pesan pada media dan juga reaksi yang timbul dari audiens. Hidajanto dan Andi juga memperjelas bahwa prinsip stimulus respon ini merupakan dasar dari teori jarum hipodermis atau teori peluru. Disebut demikian karena teori ini meyakini bahwa kegiatan mengirimkan pesan sama halnya dengan tindakan menyuntikan obat yang langsung masuk kedalam jiwa penerima pesan, atau seperti peluru yang ditembakan dan langsung masuk kedalam tubuh. ${ }^{5}$

\section{Media yang Digunakan KPU dalam Menyampaikan Informasi Pemilu 2019}

Media dan masyarakat adalah dua hal yang selalu berkaitan. Sadar atau tidak sadar media massa telah menjadi bagian penting dari kehidupan masyarakat. Pesatnya perkembangan teknologi informasi dan komunikasi seperti media massa, menyebabkan terjadi perubahan dalam penggunaan media. Media massa sedikit demi sedikit membawa masuk masyarakat ke suatu pola budaya yang baru dan mulai menentukan pola pikir serta budaya prilaku masyarakat. Berbagai informasi yang disajikan oleh media massa dinilai dapat memberi dampak yang berwujud positif dan negative. Dalam pemilu 2019 KPU Kabupaten Tanjung Jabung Timur melihat peluang yang mana pemamfaatan media massa ini menjadi salah

${ }^{1}$ Dokumentasi KPUD Tanjung Jabung Timur Tahun 2019.

${ }^{5}$ Hidajanto Djamal, Andi Fahcruddin, Dasar-Dasar Penyiaran (Jakarta: Kencana Prenada Media Group, 2011) 56. 
satu terobosan yang efesien dalam memberikan informasi terkait pemilu yang dibutuhkan masyarakat Kabupaten Tanjung Jabung Timur.

Dalam hal ini KPU Kabupaten Tanjung Jabung Timur menggunakan ada media cetak dan juga menggunakan media elektronik dalam hal ini baik audio, audio visual dan juga menggunakan media social dan KPU Kabupaten Tanjung Jabung Timur juga menggunakan website resmi Kabupaten Tanjung Jabung Timur sebagai publikasi resmi dari KPU Kabupaten Tanjung Jabung Timur selain itu juga KPU Kabupaten Tanjung Jabung Timur menyasar ke youtube sebagai jejak digital untuk penggunaan media dalam rangka mensosialisasikan atau meminformasikan kepada public terkait tahapan pemilu $2019 .{ }^{6}$

\section{Intensitas Penggunaan Media Visual dalam Menyampaikan Informasi Pemilu} 2019

Media massa visual adalah alat yang digunakan dalam penciptaan pesan dari sumber kepada khalayak dengan menggunakan alat komunikasi mekanis seperti surat kabar, koran maupun majalah. Dapat kita lihat bagaimana fungsi media visual sebagai media komunikasi untuk khalayak pembaca dimana dapat dikatakan sebagai jendela pengetahuan untuk meluaskan pandangan khalayak untuk memungkinkan seseorang untuk mendapat informasi yang terjadi dilingkunan sekitar, juru baca dan menjelaskan makna terhadap peristiwa atau hal yang terpisah dan kurang jelas, pembawa dan pengantar informasi serta sebagai pengontrol social.

Penggunaan media cetak atau media visual yang digunakan oleh KPU Kabupaten Tanjung Jabung Timur sungguh lumayan besar dimana kami menyebarkan atau mensosialisasikan tahapan pemilu dengan berbagai media cetak seperti Jambi One, Koran Sabak, Helo Jambi, Aksi Post, Jambi Ekspres,

${ }^{6}$ Nurkholis, S.Ip, Ketua KPU Kabupaten Tanjung Jabung Timur, Wawancara Dengan Penulis, 27 Agustus 2019, Kantor KPU Kabupaten Tanjung Jabung Timur, Tertulis. 
Serumpun Timur, Melayu Pos, Tribun Jambi, Sorot News, Jambi Independet, Radar Tanjab. $^{7}$

\section{Intensitas Penggunaan Media Audio dalam Menyampaikan Informasi}

Secara umum Media audio adalah alat media yang isi pesanya hanya diterima melalui indra pendengaran saja. Media audio digunakan untuk menyampaikan pesan atau rangakaian pesan materi melalui suara-suara ataupun bunyi yang direkam menggunakan alat perekam suara, kemudian didengarkan kembali kepada khalayak dengan menggunakan sebuah alat pemutarnya.

Radio berbeda dengan media massa lainya. Media hanya mengandalkan suara saja untuk menyampaikan informasi kapada khalayak. Sama halnya dengan surat kabar, orang yang mendegarkan radio juga akan berimajinasi ketika khalayak mendengarkan informasi yang diberikan. Radio yang bersifat audial yang hanya dapat digunakan dengan cara didengarkan, hal ini berarti radio tidak sanggup menjalankan fungsinya sebagai media penerangan. Radio dianggap sebagai media yang mampu menyiarkan informasi yang dapat memuaskan khalayak mendengarnya meskipun hanya dilengkapi dengan unsur audio saja. KPU Kabupaten Tanjung Jabung Timur juga menggunakan media audio atau radio dalam mensosialisasikan tahapan pemilu atau informasi terkait pemilu 2019, disini media audio yang digunakan ialah Radio Sidomukti. ${ }^{8}$

\section{Intensitas Penggunaan Media Audio Visual dalam Menyampaikan Informasi}

Dalam difinisinya media audio visual adalah media yang mempunyai unsur suara dan unsur gambar. Jenis media ini mempuyai kemampuan yang lebih baik, karena meliputi kedua jenis media auditif (mendengar) dan visual (melihat). Media audio visual merupakan sebuah alat bantu audio visual yang berarti bahan atau

7 Nurkholis, S.Ip, Ketua KPU Kabupaten Tanjung Jabung Timur, Wawancara Dengan Penulis, 27 Agustus 2019, Kantor KPU Kabupaten Tanjung Jabung Timur, Tertulis.

${ }^{8}$ Nurkholis, S.Ip, Ketua KPU Kabupaten Tanjung Jabung Timur, Wawancara Dengan Penulis, 27 Agustus

2019, Kantor KPU Kabupaten Tanjung Jabung Timur, Tertulis. 
alat yang digunakan dalam situasi belajar untuk membantu tulisan dan kata yang diucapkan dalam menularkan pengetahuan, sikap, dan ide.

Media audio visual atau televisi merupakan satu jenis media massa yang sudah umum dikalangan masyarakat. Televisi menawarkan bermacam tayangan pada para pemirsanya. Mulai dari acara anak-anak, berita, acara music, komedi, reality show, iklan, film dan berbagai program lainya, yang mana semua itu mempunyai tujuan untuk memberikan informasi terhadap masyarakat.

KPU Kabupaten Tanjung Jabung Timur juga menggunakan media audio visual atau televisi dalam mensosialisasikan tahapan pemilu atau informasi terkait pemilu 2019 yang diperlukan oleh masyarakat Kabupaten Tanjung Jabung Timur, disini media audio visual yang digunakan ialah Jambi Tv, Jek Tv Jambi, Kompas Tv, Metro TV, TVRI, dan I News Jambi. ${ }^{9}$

\section{Tanggapan Masyarakat Kabupaten Tanjung Jabung Timur Terkait Pemilu 2019}

Dalam penyebaran informasi KPU Kabupaten Tanjung Jabung Timur banyak menggunakan berbagai macam media, media yang digunakan di sini ada media massa dan juga media social. Media komunikasi massa atau media massa merupakan berbagai alat dan sistem yang digunakan dalam konteks komunikasi massa. Media massa memiliki peranan penting dalam kehidupan masyarakat. Peran media massa sangat menentukan dalam penyampaian informasi serta penyebarannya. Media massa dianggap mempunyai keunggulan yang dapat mempengaruhi pikiran manusia sehingga gaya hidup dapat berubah. Pengaruh dari media dapat berupa pengaruh positif maupun pengaruh negatif.

Tanggapan adalah reaksi atau komentar masyarakat setelah melihat, mendengar, membaca, merasakan suatu peristiwa. tanggapan sendiri terbagi menjadi dua jenis, yaitu tanggapan positif dan tanggapan negatif. Tanggapan positif adalah suatu komentar atau reaksi yang bersifat optimis atau mendukung.

9 Nurkholis, S.Ip, Ketua KPU Kabupaten Tanjung Jabung Timur, Wawancara Dengan Penulis, 28 Agustus 2019, Kantor KPU Kabupaten Tanjung Jabung Timur, Tertulis. 
Sebaliknya, Tanggapan negatif adalah reaksi atau komentar yang bersifat menjatuhkan atau tidak setuju dengan suatu peristiwa atau kejadian yang ada.

Sejauh ini di dalam tanggapan dan juga respons dari stakeholder alhamdullilah pelaksanaan pemilu di Kabupaten Tanjung Jabung Timur relative berhasil, kondusif, tidak ada persoalan-persoalan yang mendasar dan semua berjalan sesuai dengan regulasi, partisipasi pemilih melebihi target nasional, tidak ada konflik horizontal yang menonjol artinya tanggapan masyarakat sangat baik atau positif dan sangat mengapresiasi kenerja dari KPU Kabupaten Tanjung Jabung Timur. ${ }^{10}$

\section{Menyampaikan Informasi Pemilu 2019 Sesuai yang Kebutuhan Masyarakat}

Media massa adalah salah satu sarana untuk memenuhi kebutuhan masyarakat akan informasi yang dibutuhkan. Media massa merupakan hasil produk teknologi moderen sebagai saluran dalam komunikasi massa. Merupakan salah satu elemen penting dalam proses komunikasi massa. Efektifitas berarti mengandung efek, ada pengaruh atau akibatnya. Efektivitas adalah pengukuran keberhasilan dalam pencapaian tujuan-tujuan yang telah ditentukan. Media massa merupakan saluran komunikasi massa. Menggunakan media, berarti kita telah melakukan proses komunikasi. Oleh karenanya, efektivitas media bisa dilihat dari sudut efektivitas komunikasi. Komunikasi dikatakan efektif bila rangsangan yang disampaikan dan disampaikan oleh sumber (komunikator) dapat ditangkap dan dipahami oleh penerima (komunikan).

Saya kira ukurannya atau indicator parameternya KPU Kabupaten Tanjung Jabung Timur bisa mengatakan ini berhasil ataupun efektif dalam penggunaan media massa sebagai sarana penyebaran informasi, hal ini dapat di lihat dari tingkat partisipasi pemilih dimana targer secara nasional itu ada $77,5 \%$ sedangkan tingakat partisipasi sementara di Kabupaten Tanjung Jabung Timur kurang lebih $82 \%$ artinya sasaran untuk mengajak pemilih untuk menggunakan hal pilihnya ini

${ }^{10}$ Nurkholis, S.Ip, Ketua KPU Kabupaten Tanjung Jabung Timur, Wawancara Dengan Penulis, 27 Agustus 2019, Kantor KPU Kabupaten Tanjung Jabung Timur, Tertulis. 
berhasil menggunakan dalam menggunakan media massa ataupun relawan demokrasi itu sendiri tugas-tugasnya berhasil terjalankan. ${ }^{11}$

Pengaruh terpaan media adalah efek yang muncul setelah seseorang membaca, mendengar dan menonton pesan yang disampaikan melalui media massa. Efek yang timbulkan dari media massa sama dengan efek yang ditimbulkan komunikasi massa, yang mana efek yang timbul dari komunikasi massa berkaitan dengan penambahan pengetahuan (kognitif), mengubah sikap (afektif), dan menggerakan perilaku audiens (behavioral).

\section{Aktivitas KPU Tanjabtim dalam Sosialisasi Pemilu 2019 Intensitas KPU dalam Menyampaikan Informasi Publik}

Informasi yang baik dan benar adalah informasi yang diproses dan diolah sesuai dengan aturan-aturannya. Sebuah informasi dikatakan sempurna apabila memiliki sifat-sifat di atas. Agar informasi dapat bermanfaat dan dipergunakan oleh masyarakat luas, maka diperlukan tindakan yang efektif oleh Lembaga yang menyampaikan sebuah informasi tersebut, sehingga dapat meningkatkan citra dari suatu organisasi sebagai media yang memberikan informasi. Hampir semua jenis informasi bersifat relatif. Semua informasi dapat berguna bagi seseorang atau organisasi yang satu, akan tetapi belum tentu bagi seseorang atau organisasi yang lain. Yang paling penting adalah bagaimana informasi tersebut dikoordinasikan dan diolah dengan sebaik-baiknya sehinga memperkecil kemungkinan gangguan atau resiko yang fatal atau informasi yang tidak valit. ${ }^{12}$

Kualitas dari sebuah informasi harus dapat menyanggah data-data yang palsu atau tidak memiliki kebenaran. Fleksibilitas yaitu sebaliknya yang terjadi disekitarnya. Sifat berikutnya mengenai ketepatan waktu, para pengguna informasi membutuhkan informasi yang terbaru. Apabila pangguna informasi

11 Nurkholis, S.Ip, Ketua KPU Kabupaten Tanjung Jabung Timur, Wawancara Dengan Penulis, 27 Agustus 2019, Kantor KPU Kabupaten Tanjung Jabung Timur, Tertulis.

${ }^{12} \mathrm{http} / / /$ pena.gunadarma.ac.id/keterbukaan-informasi-publik/ Diakses tanggal 5 maret, jam 18:47 WIB. 
disuguhkan dengan berita-berita yang sudah terlalu lama, maka informasi harus mudah dimengerti oleh orang lain. Maksudnya informasi yang diolah dan diatur dengan baik, akan memberikan keputusan tertentu bagi yang menggunakannya.

Dalam hal ini dapat saya sampaikan secara ringkas bahwa informasi yang disampaikan tentu yang pertama adalah tahapan pemilu serentak 2019, kedua yaitu tahapan publikasi mengenai daftar calon sementara dan daftar calon tetap anggota DPRD, ketiga publikasi daftar pemilih sementara dan publikasi daftar pemilih tetap di pemilu 2019, keempat yaitu publikasi peserta pemilu dalam hal ini partai politik peserta pemilu di Kabupaten Tanjung Jabung Timur, kelima yaitu teknis tahapan pemilu tentu dasarnya adalah UU No 7 Tahun 2017 tentang pemilihan umum dan PKPU dan juga juknis, keenam yaitu ajakan dalam hal ini ajakan partisipasi pemilih, ketujuh yaitu tata cara pencoblosan, kedelapan yaitu ucapan terima kasih telah memilih, dan terakhir yaitu publikasi anggota DPRD terpilih. ${ }^{13}$

\section{Kendala dan Hambatan KPU dalam Menyampaikan Informasi Pemilu 2019}

Hambatan yang terjadi di dalam proses kegiatan komunikasi massa bisa disebut sebagai komunikasi yang tidak efektif. Komunikasi yang efektif yang berarti antara komunikator dan komunikan memiliki kesamaan dalam makna pesan yang dikirim dan diterima. Komunikasi massa yang efektif merupakan jenis komunikasi yang berhasil dalam melakukan kegiatan penyampaian informasinya. Hambatan komunikasi massa ini bisa berasal dari komunikator yang kurang memberi penjelasan informasi, komunikan yang belum siap untuk menerima informasi dari komunikator, pesan yang disampaikan tidak memiliki kejelasan sumbernya, media yang digunakan tidak semua dimiliki oleh masyarakat luas, dan adanya feedback yang tertunda. Hal hal tersebut bisa menjadi faktor penghambat dalam kegiatan komunikasi massa

13 Nurkholis, S.Ip, Ketua KPU Kabupaten Tanjung Jabung Timur, Wawancara Dengan Penulis, 27 Agustus 2019, Kantor KPU Kabupaten Tanjung Jabung Timur, Tertulis. 
Sebagaimana halnya tidak dapat dipungkiri lagi bahwasanya dalam setiap melakukan kegiatan komunikasi massa dalam sebuah organisasi tentunya pasti akan mengalami Kendala dan Hambatan yang merupakan halangan atau rintangan yang menjadi faktor ataupun keadaan yang membatasi, mengahalangi atau mencegah pencapaian sasaran dari komunikan. sudah berusaha untuk bekerja dengan seoptimal mungkin, namun ada beberapa kendala yang dihadapi oleh pihak KPU Kabupaten Tanjung Jabung Timur, tidak hanya yang bersifat Internal namun juga menyangkut Eksternal.

Tentu jika berbicara hambatan atau kendala mengenai penyampaian informasi pemilu di Kabupaten Tanjung Jabung Timur pasti relative ada dalam hal ini dalam wilayah geografis Kabupaten Tanjung Jabung Timur dibeberapa daerah tentu tidak terpapar oleh berbagai macam media massa baik itu cetak dan audio terkecuali audio visual seperti Televisi, yang mana audio visual sudah cukup luas jangkauannya berbeda dengan media cetak yang penyebarannya tidak sampai fisiknya kepada masyarakat dan ada juga daerah yang tidak terjangkau oleh media social karena jaringan dari internet itu sendiri yang masih lemah di daerah Kabupaten Tanjung Timur. ${ }^{14}$

Setiap organisasi maupun suatu lembaga pemerintahan seperti KPU Kabupaten Tanjung Jabung Timur ketika menjalankan suatu kegiatan tentu akan dihadapkan pada suatu hambatan, dan untuk mengatasi hambatan tersebut harus menemukan solusi yang tepat. Karena solusi merupakan titik temu dalam suatu persoalan untuk dapat teratasi dengan baik.

Jika kita berbicara hambatan, perlu diketahui bahwa hambatan merupakan hal-hal yang mengganggu suatu kegiatan dan akan berakibat pada kegagalan baik itu kegiatan dalam sebuah lembaga maupun organisasi. Dalam menghadapi hambatan biasanya harus menemukan solusi yang tepat dengan melakukan pendeketan-pendekatan untuk membangun sebuah organisasi atau Lembaga

14 Nurkholis, S.Ip, Ketua KPU Kabupaten Tanjung Jabung Timur, Wawancara Dengan Penulis, 27 Agustus 2019, Kantor KPU Kabupaten Tanjung Jabung Timur, Tertulis. 
pemerintahan. Dalam menghadapi hambatan biasanya harus menemukan solusi yang tepat dengan melakukan pendeketan-pendekatan atau terjun langsung ke kalangan masyarakat dengan melakukan seminar agar masyarakat langsung mengetahui informasi apa yang dibutuhkannya.

Untuk mengatasi ataupun solusi mengatasi kendala-kendala agar informasi pemilu serentak 2019 ini sampai kepada seuruh masyarakat karena ini adalah haknya untuk menggunakan hak pilih dimana juga tugas fungsi KPU itu salah satunya yaitu Pendidikan pemilih, dalam hal ini KPU Kabupaten Tanjung Jabung Timur membentuk Relawan Demokrasi tugas dari relasi ini adalah mitra KPU untuk menyampaikan atau mensosialisasikan tentang pemilu 2019 langsung kepada masyarakat. Relasi ini direkrut ada 55 orang dan 55 orang ini kita sebar di 11 kecamatan untuk mengatasi dan sebagai solusi dari media massa yang tidak mampu menjangkau kepada seluruh masyarakat di Kabupaten Tanjung Jabung Timur. $^{15}$

Kami sebagai anggota KPU Kabupaten Tanjung Jabung Timur juga melakukan Pendidikan pemilih dengan melakukan seminar ke berbagai sekolah SMA sederajat yang ada di Kabupaten Tanjung Jabung Timur yang mana targer sasarannya pemilih pemula yaitu anak-anak kelas 12 yang belum begitu mengerti mengenai pemilihan umum 2019. ${ }^{16}$

\section{E. Penutup}

Berdasarkan hasil penelitian penulis tentang peran media massa dalam menyampaikan informasi pemilu 2019 (Studi kasus pada sosialisasi pemilu 2019 di KPUD Kabaupaten Tanjung Jabung Timur) dapat diambil kesimpulan bahwa penyebaran informasi pemilu yang dilakukan oleh KPU Kabupaten Tanjung Jabung Timur dengan menggunakan berbagai macam media massa dan membentuk

15 Nurkholis, S.Ip, Ketua KPU Kabupaten Tanjung Jabung Timur, Wawancara Dengan Penulis, 27 Agustus 2019, Kantor KPU Kabupaten Tanjung Jabung Timur, Tertulis.

16 Nurkholis, S.Ip, Ketua KPU Kabupaten Tanjung Jabung Timur, Wawancara Dengan Penulis, 27 Agustus 2019, Kantor KPU Kabupaten Tanjung Jabung Timur, Tertulis. 
relawan demokrasi dengan tujuan untuk meningkatkan kualitas pemilu, meningkatkan partisipasi pemilih dan meningkatkan kepercayaan public terhadap proses demokrasi. Kemudian menjadi beberapa bagian yaitu:

1. Media yang digunakan oleh KPU Kabupaten Tanjung Jabung Timur dalam menyampaikan informasi pemilu 2019 yaitu dengan mengunakan berbagai macam media massa baik itu cetak, radio, televisi dan juga membentuk relawan demokrasi dengan tujuan agar dapat menetralisir media massa yang terbatas jangkauannya.

2. Informasi yang disampaikan oleh KPU Kabupaten Tanjung Jabung Timur terkait pemilu 2019 yaitu berupa tahapan pemilu, daftar calon sementara DPRD, daftar pemilih sementara dan tetap, daftar peserta pemilu, teknis tahapan pemilu, ajakan partisipasi pemilih, tata cara pencoblosan, ucapan terima kasih telah memilih, maupun publikasi anggota DPRD terpilih.

3. Kendala dan hambatan KPU Kabupaten Tanjug Jabung Timur dalam menyampaikan informasi pemilu 2019 yaitu, media cetak yang penyebarannya tidak sampai bentuk fisik kepada masyarakat, juga media audio yang masih minim aksesnya di berbagai daerah-daerah dan juga jaringan internet yang masih lemah guna untuk mendapatkan informasi di berbagai media online diberbagai wilayah Kabupaten Tanjung Jabung Timur.

\section{Daftar Pustaka}

Galuh Kartiko. Sistem Pemilu dalam Perspektif Demokrasi di Indonesia. Jurnal Konstitusi, Volume II, Nomor 1 Juni 2009.

http://pena.gunadarma.ac.id/keterbukaan-informasi-publik/ Diakses tanggal 5 maret, jam 18:47 WIB.

Hidajanto Djamal. Andi Fahcruddin. Dasar-Dasar Penyiaran. Jakarta: Kencana Prenada Media Group, 2011. 
McQuail, Dennis. McQuail's Mass Communication Theory. New Delhi: SAGE Publication, 2000.

Nurkholis, S.Ip, Ketua KPU Kabupaten Tanjung Jabung Timur, Wawancara Dengan Penulis, 27 Agustus 2019, Kantor KPU Kabupaten Tanjung Jabung Timur, Tertulis.

Nurkholis, S.Ip, Ketua KPU Kabupaten Tanjung Jabung Timur, Wawancara Dengan Penulis, 28 Agustus 2019, Kantor KPU Kabupaten Tanjung Jabung Timur, Tertulis.

Seputar Pengertian, "Pengertian KPU Beserta Fungsinya", diakses melalui alamat http://seputar pengertian.blogspot.com/2015/12/pengertian-kpu-besertafungsinya.html, tanggal 27 Juni 2019.

Sugiono. Metode Penelitian Kuantitatif, Kualitatif, dan R\&D. Bandung: Alfabeta, 2010. 